\title{
Effects of COVID-19 on maritime industry: a review
}

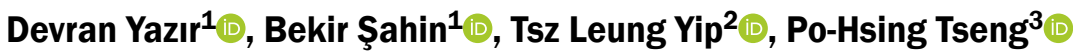 \\ ${ }^{1}$ Surmene Faculty of Maritime Sciences, Karadeniz Technical University, Trabzon, Turkey \\ ${ }^{2}$ Department of Logistics and Maritime Studies, the Hong Kong Polytechnic University, Hong Kong \\ ${ }^{3}$ Department of Shipping and Transportation Management, National Taiwan Ocean University, Taiwan
}

\begin{abstract}
COVID-19 is a global disease that has quickly shaken the world economy since the beginning of 2020 and consequently has significantly affected the shipping industries development (including shipping operators, port operators, government authorities, shippers, seafarers, passengers, supply chain operators, etc.). Currently, the clinical management of COVID-19 remains unclear. In order to understand the newest challenges and figure out potential solutions for the maritime industries post COVID-19, this paper selected four shipping industries (including dry bulk, tanker, container, and cruiser sector) and reviewed these industries' newest development. The research findings can strengthen the awareness of COVID-19 and reduce operational risk and further improve business performance for the maritime related industries and authorities.
\end{abstract}

(Int Marit Health 2020; 71, 4: 253-264)

Key words: COVID-19, coronavirus, shipping industry, tanker, cruise

\section{INTRODUCTION}

With the reference to the warning of the World Health Organization (WHO) against various pneumonia cases that were detected in Wuhan city on December 31, 2019 in China. The information regarding an outbreak risk began to spread rapidly in the world. Chinese authorities announced on January 7,2020 , they have identified a new type of virus related to viruses like SARS and MERS. This new virus was temporarily called '2019-nCoV'. On 11 February 2020, WHO announced that COVID-19 was the official name for the disease induced by the new coronavirus [1]. COVID-19 has resulted in the deaths of hundreds of thousands of people worldwide since December 2019 [2].

It has also contributed to significant declines in economic development and had major impacts on several national economies. In some countries, since measures have been taken to safeguard public health, industrial production and energy usage have been decreased by up to $30 \%$ in only a few weeks [3]. Most of the food supply chains were harmed or threatened by the outbreak of COVID-19.

Lack of intermediate goods from China due to COVID-19 caused many companies to suffer. Commodity prices dropped; especially crude oil saw the lowest prices in history. People's travel opportunities have been restricted, the transportation and carrying sector has been adversely affected. As a result, almost all countries shrank in the first quarter of 2020 . This situation naturally caused economists to make some predictions for the rest of 2020 according to pessimistic and optimistic scenarios. According to these scenarios, even if the global economy improves in the second half, 2020 will not be very good both in terms of the global economy and global transportation. This situation can be seen from the growth expectations of the International Monetary Fund (IMF) [4].

The container industries have faced many new challenges in recent year, such as trade regulation (e.g. US-China trade war), shipping fleet deployment, green shipping and green port issues (e.g. sulphur content in fuels). The emergence of COVID-19 has brought new challenges for shipping operation and management. For example, security check of port can result in extra waiting time for berthing operations, inland seaport transshipment operation, hinterland transportation management, etc. The change of trade volume affects the freight and charter rates in the 
container shipping market and shipping operators must think how to figure out resilience strategies to reduce the potential operation loss and make this market back on a growth track.

During the early of the year 2020, many cruise ships have berthed at ports empty of passengers due to the influence of COVID-19. The spread of viral pandemics has made this industry face serious challenges since it has involved public health and life safety problems. Past studies have mainly focused on specific case (e.g. Diamond Princess Cruise Ship) $[5,6]$ and explored treatment process. The insight studies of analysing market response strategies for COVID-19 outbreak period in the cruise industries are still limited. These contents will be further analysed and help cruise industries pass COVID-19 storm and develop new market opportunities.

This paper provides a comprehensive literature review to criticise the effects of COVID-19 on shipping industry. As COVID-19 is new to academia and the world and has yet to be researched, we tried to combine all related sources such as academic papers, magazines and corporate websites. It is believed that this study will contribute to fighting COVID-19 in shipping industry by increasing the awareness and taking measures and pre-cautions.

\section{DRY BULK SHIPPING}

It can be stated that with the global pandemic of COVID-19, the agricultural sector's versatility has been tested. The global downfall in the demand of hotels and restaurants, caused agricultural commodities prices to drop by $20 \%$ [7]. Countries around the world have taken several preventive actions to manage the exponentially rising spread. Nonetheless, aside from the restaurant and hotel services, most of the agriculture and food supply chains were considered in much better condition than the general economy during the pandemic [8].

Unquestionably, that is because people continue to consume, and particularly, stock up on dry food based on their stay at home. However, the food industry has been challenged by panic-stricken people who stockpile excessively [9]. This has led to increased concerns about food shortages in sterilized milk, pasta, rice, and canned foods. This high demand for food products also hindered the delivery of online purchase food. Dry food and detergent sales have been exploded online, and while companies struggled with excessive demands, orders were delivered late or never arrived at all [10].

To put it another way, concerns about food shortage mean that the vulnerable population that cannot afford to stockpile food would not be able to find food. The result was the implementation of new restrictions to provide food to those who need it most of time [11].
Besides the aforementioned information, the poor countries and their food shortages have become more prevalent rapidly with the global epidemic $[12,13]$. Accordingly, governments have taken various measures to protect the integrity of food supply chains. Therefore, besides compromising human health, it can be said that pandemics have posed major economic and sociocultural hazards $[14,15]$.

Even though the agriculture sector's economic risks are deemed lower during the pandemic, if agricultural supply chains continue to crumble, employees are more likely to suffer because of employment gaps or an increase in the working hours. The reason for this can be stated as agriculture is the main industry that provides for $37 \%$ of total employment opportunities, and most of the paid agricultural workers are working seasonally and without social security [16].

Agricultural products are transported by land route, railway, and seaway. Dry bulk is transported to ports by land and rail, and between ports by seaway [8]. Throughout the pandemic, every dry bulk trade mechanism was influenced significantly by COVID-19 outbreak-related interventions. Since governments limited transport connections with other countries according to the physical distance rules, this situation particularly affected the trade performed via international maritime transportation [17].

As maritime shipping constitutes approximately $90 \%$ of global goods trade, disrupted port facilities prevent the distribution of imported food. International Maritime Organisation (IMO) has therefore consistently stressed the significance of not inconveniencing the maritime trade [1]. It has also highlighted the necessity of taking certain health measures for this. After the disclosure of the pandemic, cargo ships with bulk ocean freight have been equipped with crews isolated from residents on the mainland due to the fear of transmitting COVID-19 on board. Since the marine containers could not make new loading during their return to Asian countries that are frequently importing, empty container problems arose [18]. Therefore, due to the pandemic, spending extra time and money turned into a necessity for a new loading. For example, a health screening was required for the crew, so the landing was prohibited. Harbours were in a state of deadlock due to the shortage of workers and failing to carry cargo quickly; thus, refrigerated warehouses have become unusable for fresh food [19]. These delays caused perishable goods to spoil in a short-time and increased food waste. Also, the suspension of containers during the quarantine period caused serious economic problems in maritime trade.

As seen in Figure 1, the Baltic Exchange Dry Index started to fall in October 2019 and continued to downward momentum by reaching more than $80 \%$ fall in February 2020. After that date, certain rises were observed and levels in November 2019 were almost achieved in July 2020. 


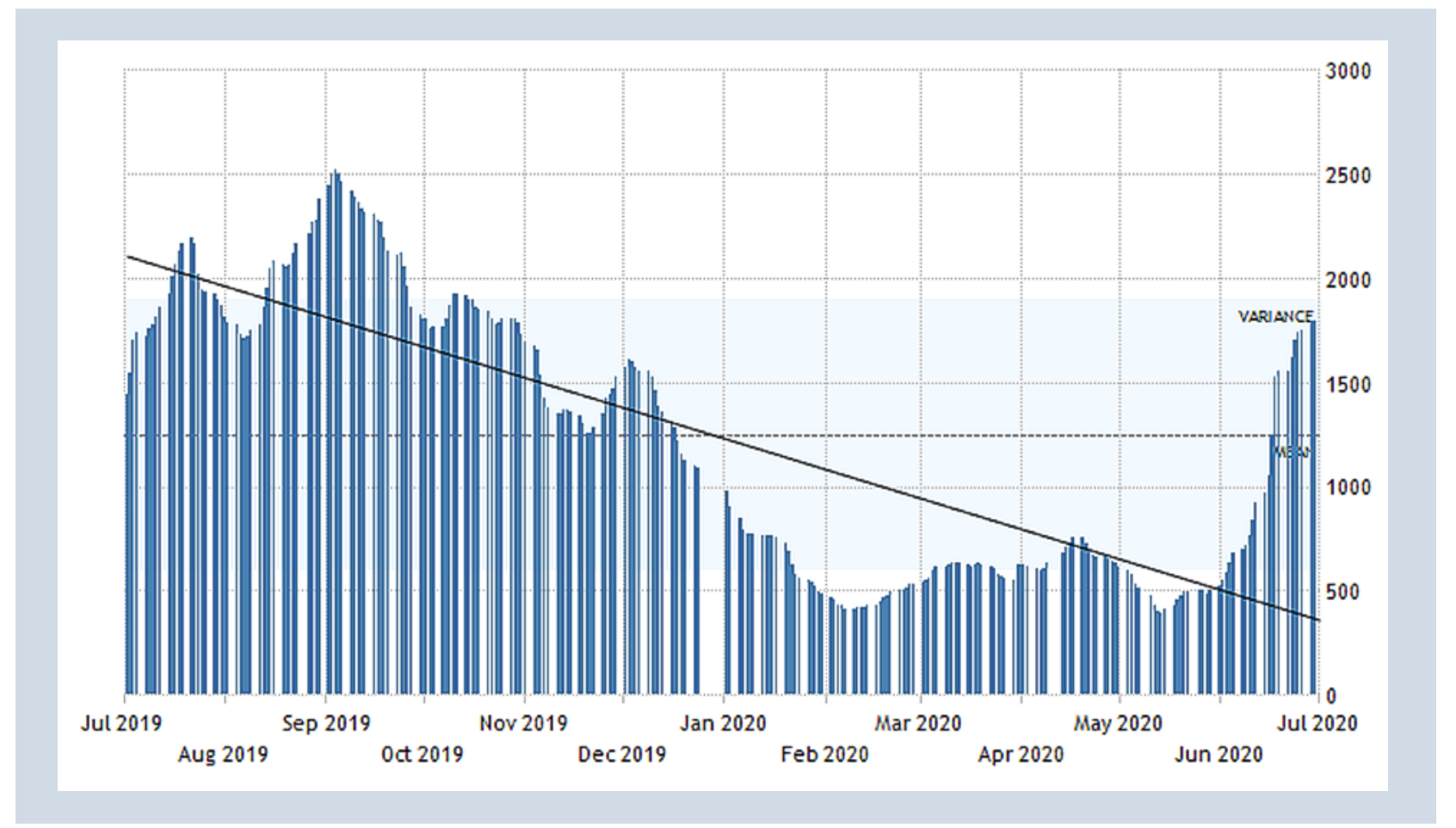

Figure 1. Baltic Exchange Dry Index Monthly Open Values [23]

The coronavirus (COVID-19) outbreak increased food safety risks in Asia and the Pacific. Since the increased health risks have led to travel restrictions, disruptions in domestic and international food supply chains have reduced food availability and accessibility [20]. In addition to international transportation and logistics limitations, interruptions experienced in food supply chains also stem from the travel restrictions and employee sicknesses observed during the planting and harvesting period [20]. Employment gaps and income losses also put people at risk of starvation and malnutrition. Besides, the international lockdown of borders and export restrictions limited import-dependent countries' access to certain food products [20].

Following the announcement of COVID-19 as a pandemic, food prices in India, which is among the countries where dry food is produced most in Asia, have increased considerably since transport services have been suspended and fresh materials were not accessible [21]. This situation has damaged the harvest of wheat in Northern India, while volunteer students were sought for the harvest of grapes in Pune. Owing to the fear of contamination, onion harvesting was hindered at Maharashtra due to the fleeing of drivers and personnel. Food processing operations have ceased notwithstanding the high demand for processed foods such as instant noodles and biscuits. Giant food companies like Nestle and PepsiCo were unable to boost production since all workers returned to their villages. Afterward, flour and grain imports decreased significantly due to export bans on wheat in Uzbekistan. Owing to disruptions in the global supply chain and distribution networks generated by the pandemic, Indonesia has limited its import capacity. The transport of dry food was restricted in the People's Republic of China, and the delivery of agricultural products was interrupted due to labour shortages [22].

Furthermore, it was found that the demand for food is decreasing due to certain factors. According to Michael Bourke [12], COVID-19 would possibly reduce the supply of both fresh and dried products traded as follows:

- greatly decreased change-ability of the population and possible interruption of transport/supply chains;

- spoilage in fresh food marketing and, accordingly, increases in fresh food prices;

- interruption of supply of foreign food chains, such as products dependent on rice and flour;

- disruptions in the supply of food chains based on sugar, eggs, poultry, pork products, and canned tuna fish;

- closing of many shops because of lack in supply or civil disorder;

- loss of income by many people in both the formal and grey economy, and thereby, a decrease in purchasing power of food that affects rural and urban people.

The combination of trade-policy shocks and COVID-19 seems to have triggered a major storm. A single incident may not be sufficient to prompt the rethinking of 
global value chains; however, the two can be merged. The US-China trade battle, the current restrictions on the export of medicinal and agricultural goods, has created uncertainty regarding the future of free trade [24]. Ergo, global value chains linked to dry grain and sea transport have been assumed to be reshaped after the pandemic.

Scientists warn us that extreme weather conditions caused by climate change and infectious diseases will trigger new outbreaks [25]. In case of a determined action against climate changes and epidemics have not been taken, resonant shocks in the global economic system would have become widespread. Countries would need to diversify their supplier sources to prevent problems affecting a specific supplier or geographical region. For instance, numerous Eastern European and Eastern and Southern Mediterranean countries have a competitive advantage over goods exported by China [26]. Countries firstly will need to increase their development efforts regarding export by maritime transport and dry food investment to seize the opportunity to enter global value chains or intensify their share.

\section{TANKER AND LNG SHIPPING}

\section{TANKER SHIPPING MARKET IN TURMOIL}

Opinions and concerns about the problems that COVID-19 will cause in the maritime sector were conveyed to the European Union by the European Community Shipowners Association (ECSA) and the European Transport Workers' Federation (ETF). In the letter, it is stated that the measures to restrict the movement of people to minimise the risk of infection in many countries are understandable, but these measures also have serious consequences on the movement of seafarers. Also, the closure of the ports is stated as a related effect. Moreover, it is emphasized that workers on both the sea and the land experience various problems that require urgent intervention. It was said in the letter to be very important for the ships to approach the port when necessary and for the personnel to join and leave their ships with as few obstacles as possible. Also, this situation was getting harder with the restrictions in the ports and the reductions of the flights. The shipping industry, therefore, called on the operator and owner to continue operating the ship. It also said crew members have the flexibility to enable them to leave the ship and return to their homes. It also requests that the crew members are exempted from national travel prohibitions so that they can join their ships and maintain the operability of their supply lines. It was reported that seafarers should be treated differently when they return to their countries, and just like healthcare professionals and security forces, seafarers are key employees. So, it was stated that governments should pay special attention to seafarers in this way [27].
Seafarers who are not allowed to leave the ship due to travel restrictions may be forced to stay on the ship longer than usual. Besides, educational institutions such as the Training Support Command (TSC) San Diego were closed to limit the spread of the virus. Due to concerns that certificate periods may expire as a result of seafarers failing to receive the necessary training to extend their certificates, the United Kingdom Maritime and Coast Guard Agency (MCA) advises on seafarers' training as the COVID-19 outbreak continues. In this context, the maritime sector called on the Flag and the Port States to extend the validity period of the certificates for at least 3 months and demands that regional Port State control regimes around the world act for this situation [27].

In the January-February period of tanker transportation, China's daily oil shipment fell by almost 0.4 billion tons from January 10 to February 18, from an average of 3.5 billion DWT. However, with the fall of oil prices, oil shipment increased again. In the period until the first week of April, both crude oil imports and iron ore imports increased by $2 \%$ compared to the same period of 2019 [4].

After a bad 4.5-5 months in terms of many segments of maritime transport (excluding tanker transport), the pandemic is controlled, and then the pandemic can be finished at the end of May and if the second outbreak does not appear, the remaining 8 months may be better. In the following times, a higher trend may be a maritime sector in 2021 by all segments. But the remedy for this improvement may be the cause of a new debt crisis in 2022-2023 [4].

According to the data of BIMCO, the COVID-19 pandemic influenced all over the world, causing delays or cancellations of contracts in the shipbuilding industry and postponement of new building deliveries. Shipbuilding contract activities fell by 55\%. Ship deliveries decreased by $16.7 \%$ in the first quarter of this year compared to the same period last year. Both parts of the tanker shipping industries saw deliveries reduced by half compared to the first quarter of $2019 ; 49 \%$ and $43 \%$, respectively for crude oil and product tankers. While 5.7 million DWT crude oil tankers were delivered in the first quarter of the year, 4 million DWT of them came from the delivery of 13 Very Large Crude Carrier (VLCC) [28].

Petroleum exporting countries have found a storage formula to take advantage of this period after oil prices, which have experienced a historic decline. Refineries, which fill their tanks with cheap oil to the brim, searched for more rental tankers. While the rental prices of tanker ships are rising, the value of companies is rising rapidly. The coronavirus epidemic, the giant sector of centuries changed the balances in oil [27].

Stopping travel due to epidemic disease and interruption of hundreds of businesses has reduced oil consumption from 100 million barrels to 30 million barrels. This led to 
a rapid decline in oil prices. The price of Brent oil, which was traded at $\$ 66$ a year earlier, fell below $\$ 20$ a barrel. Oil importing countries closely follow the oil market to benefit from the low price in oil [27].

While storage companies are looking for tankers to transport oil from all around, sector agents say that it is difficult to find a rental tank for a while. Maritime companies' officials state that the rents of tanker ships have lined with the increase in demand. In international markets, the share values of tanker companies started to increase rapidly [27].

Long Range 2 (LR2) product tankers (80,000-119,999 DWT) daily earnings were $\$ 165,000$, whereas before 2001 it was around $\$ 80,000$. Aframax (750,000 DWT) crude oil tanker earns almost the same money daily as VLCC crude oil tanker, which takes more than 2 times crude oil. The daily income of Long Range 1 (LR1) product tankers (55,000-79,999 DWT) is $\$ 110,000$ and the previous gain is around $\$ 65,000$. Medium-range (MR) product tankers (25,000-54,999 DWT) daily earnings are around $\$ 75,000$, and Handysize $(10,000$ -24,999 DWT) daily earnings are around \$90,000 [29].

As almost all land refineries are full, so, product tankers are used as storehouses. Therefore, as the demand for product tankers has increased, the profit of these tankers has increased more than ever [29].

Due to the tightness in large tonnage VLCC and Suezmax tanker ships, very few loadings and unloading ports serve such ships in the open sea [29].

Although MRs, Handysize, and LRs type tanker ships do cargo loading and unloading in different hemispheres, they have been left in the discharge port for a long time and caused the ships to be used as warehouses [29]. Crude oil tankers are used as warehouses due to the decrease in crude oil prices and the increase in prices in the future, because of the buy-to-sell strategy [29]. COVID-19 caused a lack of demand all over the world. Therefore, the depreciation in the crude oil market prices is expected to continue for a while. And crude oil ships are used as warehouses for a long time and the freight prices of these ships are expected to increase due to excess demand [29].

The maritime and tanker sector is in a vicious circle due to the epidemic. It is said by the authorized people that there is a big decline in the industry in the world and we are still in the middle of this decline. It is also estimated that this situation will continue for a while [30].

According to the report of Diamond S maritime company, the first quarter of 2020's ship rental net income was 45 million dollars and it was seen that it decreased 1 million dollars compared to the first quarter of the previous year [30]. Oil supply to ships has decreased due to the confusion in the oil market, although this has a positive effect on ship charter rates. However, long waiting times for vessels negatively affect shipowners [30].
Fifty-four per cent of the Suezmax crude oil tankers operating at the Diamond S shipping company were rented in the first quarter of 2020 with the spot. In the second quarter of the year, the daily rents of this type of ship increased to $\$ 48700$ and remained below expectations [30].

In January and February 2020, Suezmax tankers were rented at a low rental price. While these ships were expected to evacuate in March and April, they had to wait idly during these months due to logistics restrictions, oil refineries being closed, and refineries being full.

The shipowners suffered losses during this period as the demurrage paid by the hirer was less than the daily rent on empty waiting days [30].

Eighty per cent of Diamond S maritime company ships are operated as spot and $20 \%$ as time charters. Due to the pandemic in the world, spot market ship rents are expected to decrease in the future. For this reason, it is estimated that time charter ship rentals will gradually increase in the tanker market [30].

In the process of the epidemic, tanker shares cause financial damage to its investors in a short time. In the long term, the coronavirus epidemic should pass in a short time for the shares to profit their investors. This stagnation will continue from 2020 through 2021 when tankers are used as warehouses due to the epidemic. Also, whenever the world economy returns to normal, the recession will end. It is estimated that the markets will stop decreasing in the first quarter of 2021 [31].

The International Energy Agency (IEA) explains that quantity, time graph, and estimates for the use of oil as a floating tank in tankers are interpreted in Figures 2, 3 and 4 [31].

According to Webber Research and Advisory data, VLCC ship daily rents in 2020 are estimated to be $\$ 85,000$, and VLCC ship daily rents will be $\$ 65,000$ in 2021 [31].

According to the analyses, the usage, daily earnings, and estimated earnings ratios of VLCC ships are as indicated in the chart [31]. According to the 2019 annual report, Liquefied Natural Gas (LNG) demand is $12.5 \%$ around the world. This corresponds to 359 million tons. Due to LNG's low carbon emission, its demand is expected to double by 2040. In 2019, Bangladesh, India, and Pakistan recorded the highest growth in demand (19\%) from Asian countries, besides China's 14\% supply growth. Although the LNG tanker market is stagnant in a short time due to coronavirus, it is estimated that the market will grow gradually since the demand will increase after 2020 [32].

\section{THE EFFECT OF COVID-19 DISEASE ON THE MARITIME SECTOR AND FUTURE FORECASTS}

COVID-19 significantly affected the maritime industry. Damage to the maritime industry, which has an important 


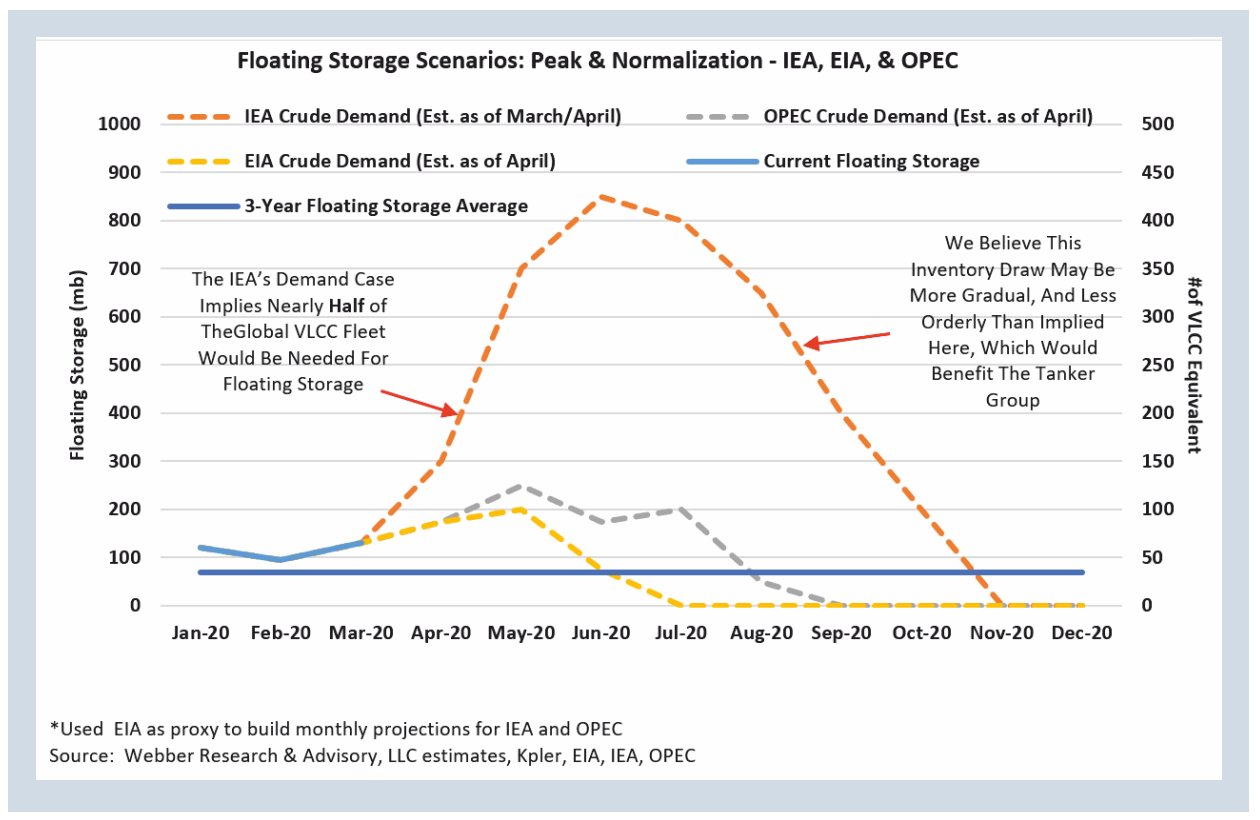

Figure 2. Floating storage scenarios [33]

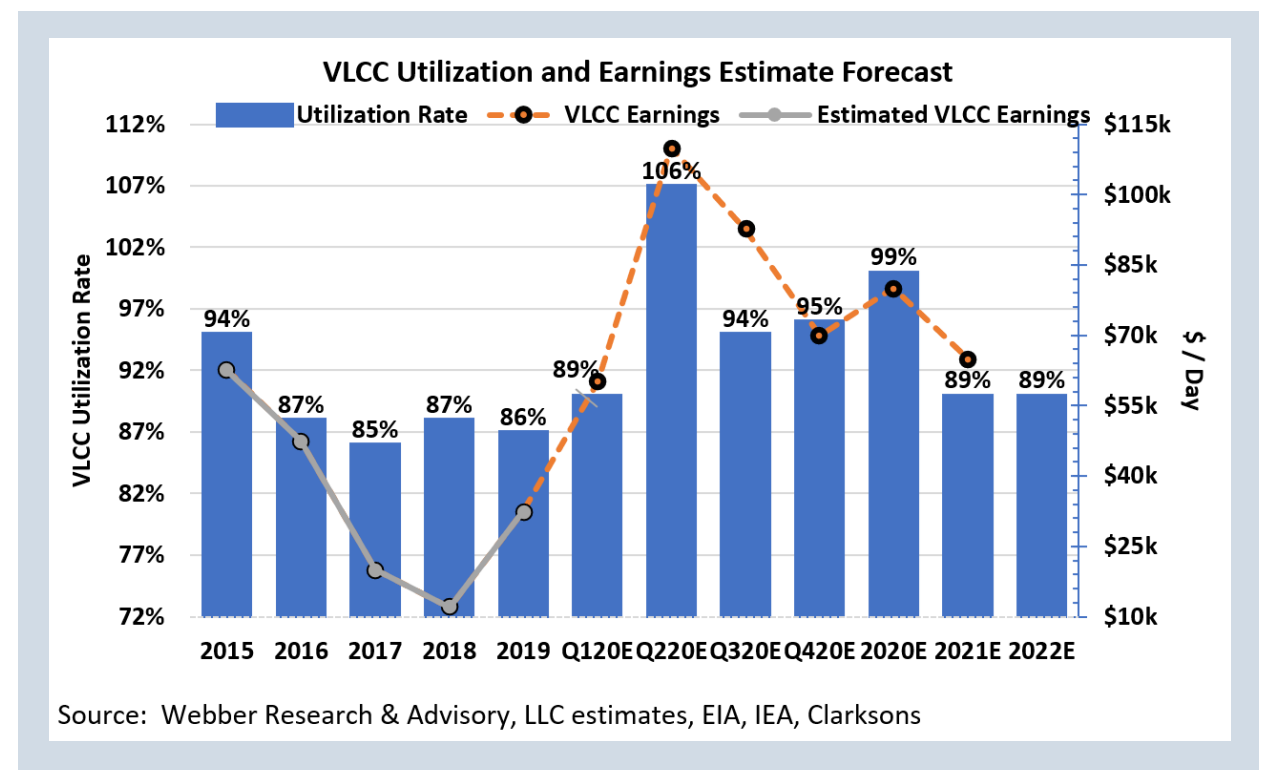

Figure 3. VLCC utilisation and earnings estimate forecast [33]

share in the conduct of trade activities in the world, will indicate the effect of this negativity in a short time. Unfortunately, developing countries like us will get their share from this negatively. It seems that there is still no definitive solution for COVID-19 and countries are still spending on their capital. Now, even if we haven't felt the effect of this so far, it is clear that this situation will lead to an economic crisis soon.

As is known, the incubation period of this virus is 14 days. Therefore, the first thing that comes to mind in the maritime sector will be an important question "whether the ships coming to the ports will be kept for 14 days to be able to take free practice". Especially, the arrival of the ships coming to/going from places where the ports of calling such as China, Italy, Spain, USA, etc. show the effect of Corona (taking into account the death cases) during this period will cause the maritime trade. Large accumulation, delays, and commercial losses will arise from this situation. In addition, inspections will become more frequent on ships and new checklists will be created. 


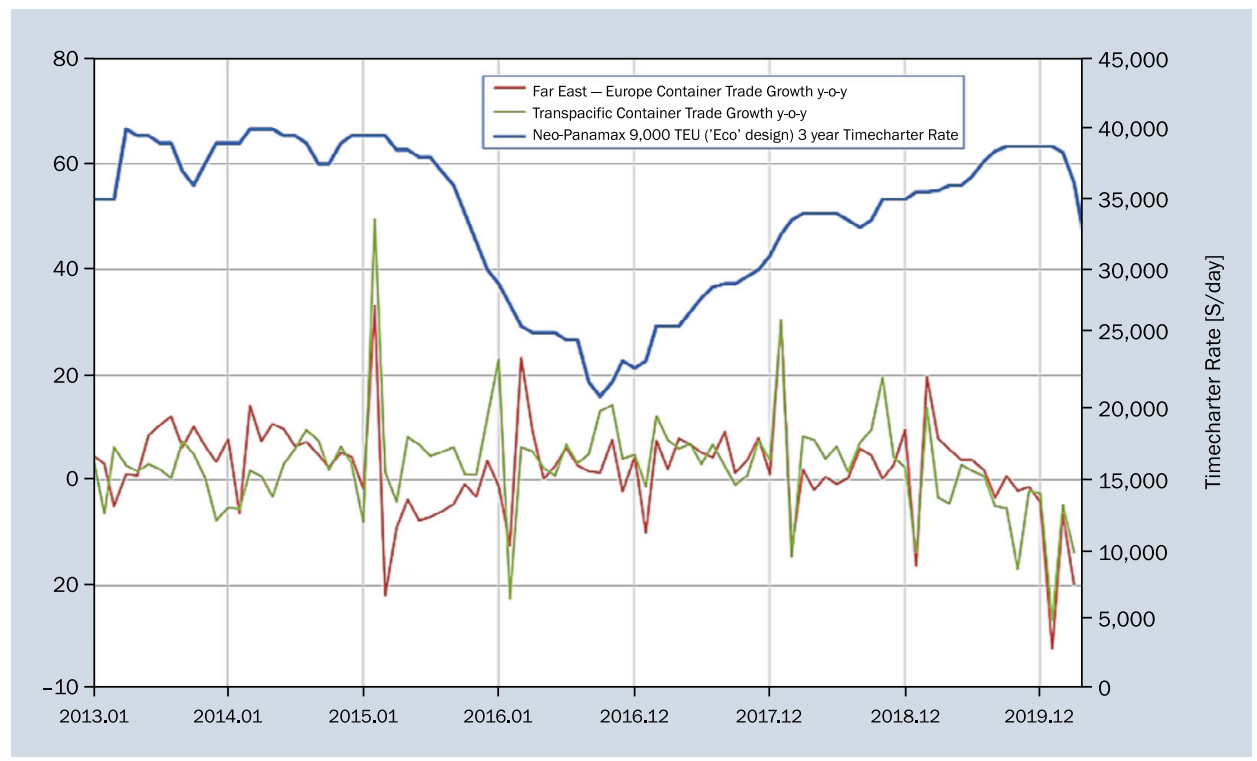

Figure 4. Global container throughput and container trade [35]

It has been also seen in the guide published by the Turkish shipowners' association; the pre-survey inspection intervals for Turkish Flagged ships in Port Directorates have been extended. Besides, Port State Inspection applications to foreign-flagged ships have been suspended, and mandatory surveys and certificates have been extended. These show that there will be some breaks in these lines and their repair time will have an effect over time. Suspension of personnel certification procedures will lead to accumulation and confusion in the next stage.

At the same time, it will be more difficult for ship crews to go out in the usual ports. When the outgoing personnel come back to the ship, they will be quarantined for a while and will create extra work burden such as take someone's temperature by the relevant officers.

How healthy the replenishment to be made to the ships will become controversial. Besides, garbage from ships will be questioned. From now on, it will be discussed that there is also a warehouse for the garbage received from ships and the disposal of the garbage in this warehouse. New standards and classifications will emerge in the garbage system.

Restrictions and regulations will come for the crew to leave the ship. Currently, the changes seem to be postponed in many countries. The Maritime Labour Convention (MLC) will be revised. Countries that will consider the incubation period of COVID-19 will also emerge in crew changes and it will be considered that the ship has not visited any port in the last 14 days. However, for those leaving the ship, there will also be a follow-up period and whether the crew leaving the ship experience any symptoms.

Cruise ships and maritime tourism will also suffer greatly from this situation. Sectors such as these will be given more care and attention because the rich people's life is very valuable. This sector may suffer for a long time if the necessary measures are not taken.

"Electronic solutions" will enter our lives in a short time to make communication and transactions with the ship crew faster. E-signature will increase. Besides, if internet access can be provided anywhere in the world, which is the project of Elon Musk, human-ship control will be provided with camera systems. Over time, a great advance will be taken to accelerate the transition to a fully artificial intelligence ship control. Moreover, investment in transportation systems such as "hyperloop one" will be further increased and these studies will be given new momentum. This means that in the future time, it may leave some of the loads on maritime transport to a new system in a faster process than expected.

\section{CONTAINER SHIPPING: SUCCESSFUL TURNAROUND}

During the COVID-19, the freight and charter rates in the container shipping segment dropped by $4.76 \%$. In 2019 , about $5.99 \%$ of the fleet was out of service (compared with $2.86 \%$ in 2018). Ivanov estimated about $9 \%$ of container shipping fleet became idle due to COVID-19 [34]. In the meantime, prices (rates) have recovered, but they are still well below their record levels just before COVID-19. Although the next few years will see additional capacity introduced into the market - and especially in the very large container ship segment-demand is likely to grow faster than supply on average. The problem of overcapacity will therefore be mitigated. In 2021, charter rates could drop by significant double-digit percentage.

The medium-term outlook for the sector is intact. World seaborne container trade is likely to expand by an average of 
$7.44 \%$ in 2021. Container shipping is thus the fastest growing mode of transport. The drivers remain the increasing international division of labour and productivity gains within the sector. All the same, container shipping increasingly finds itself faced with political and economic challenges and risks. These include stricter environmental regulation, capacity bottlenecks at ports, rising fuel prices and protectionist tendencies.

\section{SEES GLOBAL CONTAINER THROUGHPUT SINK FOR THE FIRST TIME}

The US-China Trade War of 2018/2019 hit the global container shipping business hard. World seaborne container trade fell for the first time in the annals of the sector in 2020 , contracting by $-8.47 \%$, according to Shipping Intelligence Network [35]. Prices (freight and charter rates) fell by $4.76 \%$. At its height some $5.99 \%$ of the fleet (based on capacity in TEU) was laid up, which means that in 2019 about 300 ships had been taken out of service. International shipping lines suffered losses. The reasons for these losses are obvious: the global pandemic was marked by a slump in trading activities and investment. This had a knock-on effect on container shipping since the fortunes of the sector are very closely correlated with global trade developments.

From a regional standpoint it was the China ports that were particularly hard hit by the US-China Trade War and COVID-19. In 2019 container throughput increased by $4.4 \%$ at China ports and by $2.3 \%$ worldwide. The biggest decline of around 6\% was posted by the West Coast of United States ports (Long Beach, Los Angeles, Seattle-Tacoma) that are small by international standards. Of the world's 220 biggest ports, China suffered the decline at 5.7\% [36]. The significant drop of China external trade was one major reason. Asian ports were less affected by the COVID-19, as the pandemic environment there was much less serious than in Europe and the United States. In both the Asia (excluding China) the decrease in container throughput in 2020 was about 5.6\% [36].

\section{CONTAINER SHIPPING ENJOYS MULTIPLE ADVANTAGES}

Before the slump in container throughput in 2019, the container sector posted very high growth rates. Between 2003 and 2018, for instance, global container throughput rose by an annual average rate of more than $35 \%$. The discrepancy between the 2020 figure and the prior long-term performance highlights the scale of the COVID-19.

The reasons for the historically very high growth in container shipping include the increasing international division of labour and the growing liberalisation of world trade (e.g. China's WTO accession in 2001). Furthermore, the share of goods that are ideal for shipping via container (semis and finished products) has risen steadily over the last few years, and advances in container technology allow more and more goods to be transported via container (e.g. containers for refrigerated goods or liquids). In addition, container ships possess specific advantages over traditional general cargo freighters: shorter loading and unloading times reduce turnaround times in the port, which cuts costs. Also, the options for onward conveyance via other modes of transport are better with containers than with general cargo. Ever bigger and faster ships have enabled constant productivity gains, although the increase in capacity over recent years has cranked up the price pressure in the sector. Extensive investment in port infrastructure has been and remains essential for fast growth. Especially in Asia a very large number of container terminals have been expanded or built from scratch in the last few years.

\section{CONTAINER SHIPPING CELEBRATES AN IMPRESSIVE COMEBACK}

Global container shipping has managed a complete turnaround following the COVID-19. Global container throughput probably rose from approximately $-8.47 \%$ in 2020 to $+7.44 \%$ in 2021 [35]. The key factor in this recovery was the stock-building by the industrial sector and the swift economic recovery in many countries that was often driven by external trade. Particularly the upturn in Asia helped to get container shipping back on a growth track. The world's leading exporter, China, will boost its shipments. Other Asian economies, too, will bolster the sector. Overall, container throughput in Asia probably increased in 2021, whereas North America and Western Europe are likely to have achieved only below average growth.

\section{ASIA SETTING THE PACE}

The focus of the global container shipping sector has been steadily shifting outwards from China in any case over recent years. Some $70 \%$ of global container throughput is handled by ports in Asia. In 2019, nine out of the ten biggest container ports in the world were in Asia (namely, Shanghai, Singapore, Ningbo-Zhoushan, Shenzhen Guangzhou, Busan, Hong Kong, Qingdao, and Tianjin). In the year 2004, the figure was 6 (namely, Hong Kong, Singapore, Shanghai, Shenzhen, Busan, and Kaohsiung). China was the dominant force in this respect, being home to 6 of the current top 10 ports. Looking at container trade by shipping route reveals that at least one port in Asia is involved in around $50 \%$ of all movements. This illustrates that global container shipping not only benefits from the manufacturing in Asia of consumer goods for Western Europe or the United States, but that in addition the trade links and the international division of labour between Asian countries have also increased significantly. There are individual ports that are highly specialised in the pure transshipment of containers, 
thus operating primarily as hubs for global and regional container shipping and handling relatively little local traffic. Overall, besides China there are smaller developing countries and emerging markets (e.g. Malaysia, Vietnam, India) that are also continually investing in their port capacities.

\section{OUTLOOK INTACT - LIMITING FACTORS IN VIEW}

As previously mentioned, the short-term outlook for container shipping remains bright with annual growth in container throughput expected to average $7.44 \%$ in 2021 . Going forward, momentum will continue to be generated by the established stalwarts: the continuing increase in the international division of labour, rising incomes and consumption opportunities in many emerging markets and the thereby initiated trade flows are the most important drivers on the demand side. Rising incomes in important emerging markets - above all in China - may also enable the sector to mitigate the problem of unequal flows and thus reduce the share of empty container journeys; this would result in considerable cost savings. To date, on routes from China to Europe and the United States the share of laden containers is higher than on the return leg.

On the supply side productivity improvements suggest that container shipping will continue to post high growth rates. These include larger ships (and growing transshipment shares) as well as more efficient loading and unloading systems at the terminals. In addition, the containerization level will increase worldwide; however, the containerisation level at many ports is already high, which makes a further increase virtually impossible. Slow steaming cancels out some of the productivity gains, unless high freight rates make faster speeds more economically lucrative.

Despite this generally rosy outlook the container shipping sector faces many challenges that may limit its growth potential:

- Maritime shipping is becoming the focus of national and international climate and environmental policy. Discussion is currently underway about a variety of measures that could mitigate the negative ecological impact of shipping (e.g. $\mathrm{CO}_{2}$ and pollutant emissions). These include emissions trading, efficiency standards or reducing the sulphur content in fuels. In the end, the shipping lines face higher costs because they will have to invest in their fleets in order to comply with the new standards. In addition, the sector's competitiveness relative to other modes of transport is declining. In terms of energy consumption per transported tonne, though, maritime shipping remains the most efficient mode of transport.

- Capacity bottlenecks at the ports (e.g. terminals, inland seaport traffic) can result in waiting times for container ships as could often be observed, for instance, on the east coast of the emerging Asian countries before the COVID-19. Insufficient shipping depths also act as a brake on the sector's growth. The growing importance of very large container ships makes a deepening of the waterways/shipping lanes necessary at many ports (e.g. in India, Vietnam). The expansion of the port infrastructure required by the transport industry often flounders because of financial limitations or political resistance.

- During the global recession after the COVID-19, protectionist ideas will experience a renaissance in many countries. The danger that the liberalization of global trade becomes mired permanently is at least no lower now than before the COVID-19.

- The rising number of pirate attacks in several maritime regions (recently off West Africa, IMB report 2020) means higher costs for ship owners, for instance for insurance or for modifying their ships (e.g. installing shelters for the crews) [37].

- Many seafarers have suffered the COVID-19. The availability of qualified nautical personnel is a medium to long-term challenge for the sector; personnel costs are set to rise.

All in all, the container trade sector's growth prospects are subject to political challenges (US-China Trade War) and health challenges (COVID-19). Ultimately, however, global container shipping will remain the fastest growing mode of transport over the medium-term [38].

\section{CRUISE SECTOR}

The cruise has become a popular international transportation mode with comfortable environment (e.g. entertainment services, restaurant, hotel, etc.) in recent years [39]. Generally, one cruise can carry about 3,000 passengers at least in one trip (3-10 days or longer). It is argued that passengers easily contact each other through engaging social activities in the nearly close space during the trip. It is well known that coronavirus disease has brought significant risk in the cruise and the space characteristic of cruise has increased expansion speed of COVID-19 and brought potential risk of public health in the cruise related industries [6, 40-43].

Based on the report of Centres for Disease Control and Prevention (US), it is suggested that people with a high risk of serious illness should defer travel on cruise. Since year 2020 , cruise has brought negative image for the public due to the effect of COVID-19 and consequently affected the operation strategies for the cruise companies and related industries (e.g. terminal operators). Basically, cruise companies will reduce revenue (e.g. ship tickets, passengers' expenditure during onboard and onshore trips, terminal charging, etc.) affect the stock price of cruise industries when COVID-19 has continuously existed. Also, related industries (e.g. port authorities, travel agencies, tour bus companies, etc.) must adjust their service contents and operational strategies in order to reduce potential costs. 
Regarding past research cases about cruise issues, in Taiwan, the one Diamond Princess Cruise Ship with high COVID-19 risk passengers docked at Keelung Port on 31 January 2020 [5]. In Japan, the authorities have faced a similar problem when Diamond Princess Cruise Ship (carrying approximately 3,700 passengers and crew) docked at Yokohama Port from 20 January to 9 February 2020 [44-46].

In the United States, there were 28.4 million foreign-born workers in 2019 [47]. And these workers might come from hospitality workers who have contacted infected COVID-19 patients and potential people. In the United States, it is estimated that approximately 200 cruise passengers cases of COVID-19 were confirmed from multiple cruise ship voyages and this number has accounted for about $17 \%$ of total reported United States cases during February 3 - March 13, 2020 [48]. Sönmez et al. [49] also found that COVID-19 has resulted in mental and physical pressure on the health and safety of immigrant hospitality workers. Estimates of the reproduction number (R0) for COVID-19 are crucial to understanding the health risk on board. Based on the Diamond Princess cruise ship where an outbreak occurred on a cruise ship, it is estimated that the value of reproductive number $\mathrm{R} 0$ ranges from 2.28 [50] to 14.8 [51].

In order to make sure the health and safety of cruise passengers and crew and avoid the expansion of COVID-19, four suggestions are provided below [41, 52-54].

First, the government authorities (e.g. public health authorities and hospitals) should enhance maritime medicine techniques, treatment, and health care for already infected people and implemented effective strategies to track potentially infected passengers and understand theirs' contract history [e.g. (1) using big data to track the health status of all cruise passengers with potential contact; (2) using mobile sensor data for identifying the possible contacts; (3) Health Insurance Claims data should be strictly implemented for all cruise passengers and crew; (4) conducting preboarding screening for any potential risk people and material]. Second, the cruise ships must be equipped with suitable onboard medical facilities and qualified (available) professionals (e.g. ship's medical staff) around the clock 24/7 in order to provide initial medical care for (potentially) ill passengers and avoid disease transmission. Safety education training works for all crews and well information announcements for the passengers through public address systems should be strengthened in order to effectively respond to any emergency clinical situations. Third, cruise companies should rethink their product strategies and attract potential customers through cooperation and brand management when such a global epidemic has been controlled and cruise industries have started to recover in the future. Finally, cruise companies and government authorities should strengthen risk management abilities through effective regulation rules in order to prevent any potential or new threat (such as the sudden global emergence of COVID-19 illness) in the future. Also, resilience building is important for cruise stakeholders (e.g. cruise companies, port operators, supply chain operators, insurance companies, etc.) to maintain current profit or reduce potential loss in an uncertain market environment.

\section{CONCLUSIONS}

The maritime industries are critical in the global economy and social well-being. This review has provided a timely and relevant study to understanding the four major sectors in maritime industries with practical insights. It has conducted a systematic and concise overview of contemporary issues of maritime operations and management. It attempts to conclude with a useful discussion of challenges and disruptions that are being faced by the maritime industries.

The COVID-19 has already brought significant impacts on maritime industries since early 2020 . Based on the literature, this paper has overviewed recent industries development trends, new challenges and potential solutions regarding dry bulk, tanker, container and cruise sectors. Two research findings are summarised below.

First, the operators (e.g. shipowners, exporters, importers, terminal operators, shipping carriers, etc.) of these industries have faced operational losses and inconvenience due to health and safety consideration. For example, seafarers or passengers who entered or departed from international ports must be detected and received mandatory investigation and/or strictly quarantined for 14 days due to incubation of virus. These restrictions and regulations have inevitably affected the freight rates, charter rates, revenues and earnings as well as the utilisation of facilities and human resources. In particular, the cruise industries have faced huge losses since the cabins, nearly closed space, might increase the risk of COVID-19 infection. Second, it is believed that effective Port State Inspections based on IMO conventions and big data applications could reduce potential operation risk in the era post the COVID-19 and provide successful turnaround opportunities.

\section{ACKNOWLEDGEMENTS}

This research has been partially supported by the Ministry of Science and Technology, Taiwan (MOST109-2410-H-019-027) and The Hong Kong Polytechnic University (G-UAFE).

We also would like to thank Prof. Dr. Ahmet Soylu for his supervision, and the Norwegian University of Science and Technology (NTNU) for hosting Dr. Bekir Sahin to conduct his research.

\section{REFERENCES}

1. International Maritime Organization (IMO). (2020). Circular Letter No.4204/Add.1. http://www.imo.org/en/MediaCentre/HotTopics/ Documents/CL.4204-Add.1\%20English.pdf (Retrieved September 20, 2020) 
2. Worldmeter (2020). Reported cases and deaths by country, territory or conveyance. https://www.worldometers.info/coronavirus/ (Retrieved September 30, 2020).

3. McKibbin WJ, Fernando R. The Global Macroeconomic Impacts of COVID-19: Seven Scenarios. 2020. CAMA Working Paper No. 19/2020.

4. Sismanyazıcı H. (2020). Koronavirus dünya ekonomisini sallıyor. 7 deniz Dergisi. 44, 18-22. https://issuu.com/7denizdergisi/ docs/7_deni_z_44_e_dergi_(Retrieved May 25, 2020).

5. Chen CM, Jyan HW, Chien SC, et al. Containing COVID-19 Among 627,386 Persons in Contact With the Diamond Princess Cruise Ship Passengers Who Disembarked in Taiwan: Big Data Analytics. J Med Internet Res. 2020; 22(5): e19540, doi: 10.2196/19540, indexed in Pubmed: 32353827.

6. Dahl E. Coronavirus (Covid-19) outbreak on the cruise ship Diamond Princess. Int Marit Health. 2020; 71(1): 5-8, doi: 10.5603/ MH.2020.0003, indexed in Pubmed: 32212140.

7. Bhosale J. (2020). Prices of agricultural commodities drop $20 \%$ post COVID-19 outbreak. https://economictimes.indiatimes. $\mathrm{com} /$ news/economy/agriculture/prices-of-agricultural-commodities-drop-20-post-covid-19outbreak/articleshow/74705537.cms (Retrieved September 30, 2020).

8. Gray R. Agriculture, transportation, and the COVID 19 crisis. Canadian Journal of Agricultural Economics/Revue canadienne d'agroeconomie. 2020; 68(2): 239-243, doi: 10.1111/cjag.12235.

9. The Guardian (2020). MPs in plea to government over UK's COVID-19 stockpiling, World news, The Guardian. https://www.theguardian. com/world/2020/mar/21/mps-plea-government-uk-covid-19-stockpiling-coronavirus/ (Retrieved September 21, 2020).

10. BBC News (2020). Online shopping website Ocado suspends service. https://www.bbc.com/news/business-51941987/ (Retrieved September 22, 2020).

11. BBC News (2020). Stockpiling 'will hit vulnerable', food bank warns. https://www.bbc.com/news/uk-england-beds-bucksherts51856592 (Retrieved September 22, 2020).

12. Michael Bourke MK. (2020). Potential response to COVID-19 in PNG: support for food production. https://devpolicy.org/potential-response-to-covid-19-in-pngsupport-for-food-production-20200421-1 (Retrieved September 26, 2020).

13. Tantau M. (2020). Is Indonesia Facing a Looming Food Crisis? The Diplomat. 5 May. https://thediplomat.com/2020/05/is-indonesia-facing-a-looming-food-crisis/ (Retrieved September 22, 2020).

14. CDC COVID-19 Response Team. Severe Outcomes Among Patients with Coronavirus Disease 2019 (COVID-19) - United States, February 12-March 16, 2020. MMWR Morb Mortal Wkly Rep. 2020; 69(12): 343-346, doi: 10.15585/mmwr.mm6912e2, indexed in Pubmed: 32214079.

15. Nicola M, Alsafi Z, Sohrabi C, et al. The socio-economic implications of the coronavirus pandemic (COVID-19): A review. Int J Surg. 2020; 78: 185-193, doi: 10.1016/j.jisu.2020.04.018, indexed in Pubmed: 32305533.

16. Hurst $P$, Termine $P$, Karl M. Agricultural workers and their contribution to sustainable agriculture and rural development. FAO-ILO-IUF. ILO, Geneva 2005.

17. Arifin MD. (2020). Impacts of Coronavirus COVID-19 on the Global Shipping and Maritime Industry in Indonesia and How to Overcome the Coronavirus Outbreak Based on WHO and IMO recommendations, Project: Coronavirus COVID-19. https://doi.org/10.31224/ osf.io/6wy5c (Retrieved September 20, 2020).

18. Shih W (2020). COVID-19 and global supply chains: Watch out for bullwhip effects. Forbes. https://www.forbes.com/sites/willyshih/2020/02/21/covid-19-and-global-supply-chains-watch-out- for-bullwhip-effects/?sh=87e70d971951 (Retrieved September $27,2020)$.

19. North (2020). COVID-19: Coronavirus Outbreak - Impact on Shipping *Update*, 15 April. https://www.nepia.com/ industry-news/coronavirus-outbreak-impact-on-shipping/ (Retrieved September 24, 2020).

20. Kim K., Kim S., Park C.-Y. Food Security in Asia and the Pacific amid the COVID-19 Pandemic, ADB Briefs 2020, No. 139.

21. Food and Agriculture Organization (FAO). (2020). Local food systems and COVID-19; A glimpse on India's responses. http://www.fao.org/ in-action/food-for-cities-programme/news/detail/en/c/1272232/ (Retrieved September 23, 2020).

22. Shulang Fei JN. (2020). Local food systems and COVID-19: A look into China's responses. http://www.fao.org/in-action/food-for-citiesprogramme/news/detail/en/c/1270350/ (Retrieved September 23, 2020).

23. Economics T. (2020). Baltic Exchange Dry Index. https://tradingeconomics.com/commodity/baltic (Retrieved September 23, 2020).

24. Javorcik B. 8-Global supply chains will not be the same in the postCOVID-19 world. COVID-19 and Trade Policy: Why Turning Inward Won't Work. CEPR Press, 2020, p. 111.

25. Warning S. (2020). Coronavirus pandemic. https://www.scientistswarning.org/2020/06/04/coronavirus-pandemic/ (Retrieved October 01, 2020).

26. For Reconstruction, E. B., Development (2020). COVID-19: from shock to recovery. Regional economic prospects April 2020.

27. 7 deniz (2020). STK'lardan AB'ye mektup, 7 deniz Dergisi, 44, 74-75. https://issuu.com/7denizdergisi/docs/7_deni_z_44_e_dergi_ (Retrieved September 25, 2020).

28. 7 deniz (2020). BIMCO: Gemi inşasiparişleri düşüyor, 7 deniz Dergisi, 44 , 52. https://issuu.com/7denizdergisi/docs/7_deni_z_44_e_dergi_ (Retrieved September 25, 2020).

29. Miller G. (2020). Tanker craziness continues as product carriers hit record high. Clarkson's platou securities. https://www.freightwaves. $\mathrm{com} /$ news/tanker-craziness-continues-as-product-carriers-hit-record-high (Retrieved September 26, 2020).

30. Miller G. (2020). Tanker veteran warns on rates: The storm is coming. https://www.freightwaves.com/news/tanker-veteran-warns-onrates-the-storm-is-coming (Retrieved September 26, 2020).

31. Miller G. (2020). Tanker stocks surge as global oil market collapses. https://www.freightwaves.com/news/tanker-stocks-surge-as-globaloil-market-collapses (Retrieved September 26, 2020).

32. Miller G. (2020). Today's Pickup: Shell expects to see LNG demand double by 2040. https://www.freightwaves.com/news/todayspickup-shell-expects-to-see-Ing-demand-double-by-2040 (Retrieved September 26, 2020).

33. Webber Research \& Advisory (2020). Tanker stocks could emerge as COVID-19 relapse hedge. https://www.freightwaves.com/news/ tanker-stocks-could-emerge-as-covid-19-relapse-hedge (Retrieved September 20, 2020).

34. Ivanov D. Predicting the impacts of epidemic outbreaks on global supply chains: A simulation-based analysis on the coronavirus outbreak (COVID-19/SARS-CoV-2) case. Transp Res E Logist Transp Rev. 2020; 136: 101922, doi: 10.1016/j.tre.2020.101922, indexed in Pubmed: 32288597.

35. Shipping Intelligence Network (2020). Shipping intelligence network. https://sin.clarksons.net/ (Retrieved September 20, 2020).

36. Drewry (2020). Drewry. https://www.drewry.co.uk/ (Retrieved September 21, 2020).

37. Wong MC, Yip TL. Maritime piracy: an analysis of attacks and violence. Int J Shipp Transp Log. 2012; 4(4): 306, doi: 10.1504/ ijstl.2012.049315. 
38. Wong MC, Yip TL. Influence of transportation infrastructure on the relationship between institutions and economic performance. Marit Business Rev. 2019; 4(4): 395-412, doi: 10.1108/mabr09-2019-0038.

39. Kang J. Identifying antecedents and consequences of well-being: The case of cruise passengers. Tourism Management Perspectives. 2020; 33: 100609, doi: 10.1016/j.tmp.2019.100609.

40. Cruise Lines International Association (2020). CLIA announces voluntary suspension in US cruise operations. Washington, DC. Cruise Line International Association. https://cruising.org/en/ News-and-Research/Press-Room/2020/August/CLIA-Announces-Third-Voluntary-Suspension-of-US-Cruise-Operations (Retrieved September 19, 2020).

41. Mizumoto K, Chowell G. Transmission potential of the novel coronavirus (COVID-19) onboard the diamond Princess Cruises Ship, 2020. Infect Dis Model. 2020; 5: 264-270, doi: 10.1016/j. idm.2020.02.003, indexed in Pubmed: 32190785.

42. World Health Organization (WHO) (2020). Situation report-141 coronavirus disease 2019 (COVID-19) 9 June 2020. Geneva. WHO. https://www.who.int/emergencies/diseases/novel-coronavirus-2019/situation-reports/ (Retrieved September 29, 2020).

43. Zhu Na, Zhang D, Wang W, et al. China Novel Coronavirus Investigating and Research Team. A Novel Coronavirus from Patients with Pneumonia in China, 2019. N Engl J Med. 2020; 382(8): 727-733, doi: 10.1056/NEJMoa2001017, indexed in Pubmed: 31978945.

44. Ministry of Health, Labour and Welfare (2020). The first case of novel coronavirus infection in Japan, Tokyo. Ministry of Health, Labour and Welfare. https://www.mhlw.go.jp/stf/newpage_08906.html (Retrieved September 29, 2020).

45. National Institute of Infectious Diseases (NIID). (2020). Manual of laboratory diagnosis of novel coronavirus. Japan, Tokyo. NIID. https://www.niid.go.jp/niid/ja/labo-manual.html\#class0 (Retrieved September 23, 2020).

46. Yamagishi T, Kamiya H, Kakimoto K, et al. Descriptive study of COVID-19 outbreak among passengers and crew on Diamond Princess cruise ship, Yokohama Port, Japan, 20 January to 9 February 2020. Euro Surveill. 2020; 25(23), doi: 10.2807/1560-7917. ES.2020.25.23.2000272, indexed in Pubmed: 32553062.
47. BLS (2020). The employment situation - March 2020. Bureau of Labor Statistics, US Department of Labor. https://www.bls. gov/news.release/archives/empsit_04032020.htm (Retrieved September 27, 2020).

48. CDC (2020). Coronavirus disease 2019 (COVID-19): Cases in US Atlanta, GA: US Department of Health and Human Services, United States Centers for Disease Control and Prevention (CDC). https:// www.cdc.gov/coronavirus/2019-ncov/cases-in-us.html (Retrieved September 28, 2020).

49. Sönmez S, Apostolopoulos Y, Lemke MK, et al. Understanding the effects of COVID-19 on the health and safety of immigrant hospitality workers in the United States. Tour Manag Perspect. 2020; 35: 100717, doi: 10.1016/j.tmp.2020.100717, indexed in Pubmed: 32834958.

50. Zhang S, Diao M, Yu W, et al. Estimation of the reproductive number of novel coronavirus (COVID-19) and the probable outbreak size on the Diamond Princess cruise ship: A data-driven analysis. Int J Infect Dis. 2020; 93: 201-204, doi: 10.1016/j.jijd.2020.02.033, indexed in Pubmed: 32097725.

51. Rocklöv J, Sjödin H, Wilder-Smith A. COVID-19 outbreak on the Diamond Princess cruise ship: estimating the epidemic potential and effectiveness of public health countermeasures. J Travel Med. 2020; 27(3), doi: 10.1093/jtm/taaa030, indexed in Pubmed: 32109273.

52. Geldsetzer P. Knowledge and Perceptions of COVID-19 Among the General Public in the United States and the United Kingdom: A Cross-sectional Online Survey. Ann Intern Med. 2020; 173(2): 157-160, doi: 10.7326/M20-0912, indexed in Pubmed: 32196071.

53. Kakimoto K, Kamiya H, Yamagishi T, et al. Initial Investigation of Transmission of COVID-19 Among Crew Members During Quarantine of a Cruise Ship - Yokohama, Japan, February 2020. MMWR Morb Mortal Wkly Rep. 2020; 69(11): 312-313, doi: 10.15585/mmwr. mm6911e2, indexed in Pubmed: 32191689.

54. Subramanian S. (2020). The Ordeal of the Diamond Princess Crew. The Diplomat 22 February. https://thediplomat.com/2020/02/ the-ordeal-of-the-diamond-princess-crew/ (Retrieved September 22, 2020). 